\title{
Sustainability reporting in the energy sector
}

\author{
Barbara Kowal ${ }^{1, a}$ and Arkadiusz Kustra² \\ ${ }^{1}$ AGH University, Department of Economics and Management in Industry, Al. Mickiewicza $3030-059$ Kraków, Poland \\ ${ }^{2}$ A GH University, Department of Economics and Management in Industry, Al. Mickiewicza $3030-059$ Kraków, Poland
}

\begin{abstract}
Development of the concepts of sustainable development and corporate social responsibility has a great impact on reporting in companies. The increase of their importance has resulted in a need to create a reporting system that would provide information on not only the methods but also the results of implementation of those concepts in companies. Globally, there are many organizations that promote and support companies in the area of integrated reporting. The most popular standard for reporting non-financial data that is used by a number of companies worldwide is the Global Reporting Initiative (GRI) Guidelines. The main objective of the GRI is to support the development of sustainable economy in which companies take responsibility for the economic, social, and environmental consequences of their operations, manage that responsibility, and report all their actions. An example of a sector where the concept of sustainable development and its transparent reporting has an impact on the formation of values is the energy sector, which creates value for stakeholders and, together with the financial sector, has the greatest impact on national economies.
\end{abstract}

\section{Introduction}

The problem of strategic management based on the concepts of sustainable development and social responsibility focuses on building value for stakeholders. The value is created in appropriate assets of the company that determine its tangible and intangible capital. The forms of disclosure of information about capital are frequently financial and non-financial, which demonstrates the need for company reporting in the form of reports prepared for stakeholders.

It must be noted that the need for financial information is fulfilled by reporting which is the product of financial accounting systems. In the light of the concept of sustainable development, another important issue is reporting on intangible areas related to the company's non-financial assets. In this regard, the solutions that are adopted, although they are not obligatory, focus on sustainability reports prepared based on the guidelines of the Global Reporting Initiative (GRI).

Sustainability reports are a source of information about the effectiveness of companies in non-financial areas that are related to economic, environmental, and social efficiency. The data disclosed in the aforementioned areas fill the information gap that is due to the limitations of standard financial reporting, which focuses on tangible materials owned by companies and the resulting financial aspects. At the same time, the information gap is the cause of underestimation of the sustainable value for the stakeholders. Thus, closing this gap and proper estimation of the value for the stakeholders must be based on both financial reporting and sustainability reporting, which together constitute integrated reporting.

The concept of integrated reporting is relatively new and, as it develops dynamically, constitutes an important source of information, not only for the shareholders. At the same time, it meets the requirement of full transparency, in particular in sectors and companies whose operations depend on and are determined by a large group of stakeholders.

An example is the energy sector whose functioning often constitutes a strategic activity in a specific economy. The present article presents solutions related to the concept of reporting of sustainable development of energy sector entities and attempts to integrate this reporting with data from financial reports.

\section{Importance of the energy sector to the economy}

The energy sector, next to the financial sector, determines the strength of national economies and the possibility of their growth. The impact of the sector on the economy should be considered in a balanced approach, taking into account financial, fiscal, social, welfare, and environmental aspects.

In Poland, the share of the energy sector in the gross domestic product (GDP) was about $8 \%$ in $2014,3.8 \%$ out of which has a direct impact. At the same time, the energy sector has a significant impact on the functioning of other industries, such as mining, commerce, processing, construction, and transport. The energy sector, together with its associated sector, employs over 600,000 persons or $3.3 \%$ of all employees

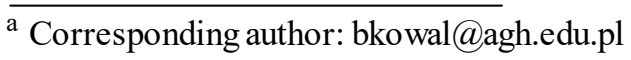


in the economy; as a result, the social aspects of its operations is significant [7].

The profitability of Polish companies is above average, even though revenues of companies in energy sectors are decreasing due to lower prices. The financial results of energy sectors translate into the taxes they pay. Of the 100 largest companies that pay the highest corporate income tax in 2013 , about 20 are companies from the energy sector, which have paid in total about 2.3 billion zlotys in taxes [8].

The largest final consumers of energy are households (approx. 31\%), transport (27\%), and industry - mostly construction (23\%) and services (13\%). The energy intensity of the Polish economy is gradually decreasing as a result of more efficient generation sources and lowed demand by individual consumers and businesses. Despite the drop of energy consumption in Poland, the demand reported by the economy is much higher than in countries of the European Union [7].

According to government forecasts, by 2030, despite the increase of the GDP, there may be a "zero energy" increase of demand for energy.

According to a PwC report published in 2016, the biggest challenges to the Polish energy sector include [6].

- maintaining profitability of production taking into account a mix of sources;

- innovativeness associated with business objectives;

- concentration on customers and offering them suitable and uncomplicated services;

- further integration on the operational level that ensures competitive advantage; and

- digitalization of decision-making processes.

\section{Sustainable development of the energy sector in the light of value creation}

Due to their special and important role in the economy of the country and their strategic importance, companies in the energy sector must focus not only on building their value but also on increasing that value. Consequently, their supreme objective is to generate value for all groups of stakeholders, which include, among others, shareholders, owners, members, the management board, customers and employees, as well as collaborating companies, financial institutions and investors (Figure 1).

Due to the large number of stakeholders, efforts to meet their expectations are not easy but they determine the priorities in operations. According to the study on awareness of Corporate Social Responsibility in Poland, stakeholders identify three main issues on which companies from the energy and fuel sector should concentrate [3]:

- care for the national environment (81\%);

- care for the safe labor of employees (81\%);

- ensuring secure supply of energy $(80 \%)$.

All such activities must be subordinated to the supreme objective and, at the same time, must meet the criteria of sustainable development and social responsibility. Value creation by companies from the energy sector should be performed in a sustainable manner.

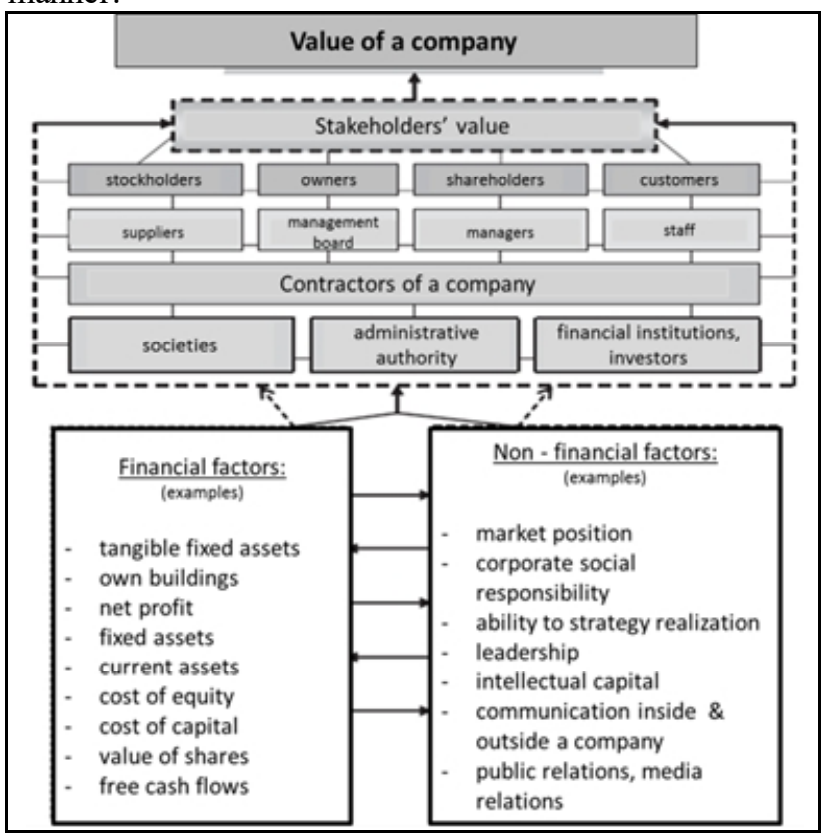

Figure 1. Elements of company's value creation (Source: author's own study)

This means combining tangible and intangible aspects (factors) on the one hand and financial, social, and environmental aspects on the other hand. Taking into account the aforementioned factors that influence generation of value of such companies leads to creation of a durable, sustainable value for the company, its shareholders, and the society at the same time.

\section{Integrated reporting}

The increase of the importance of the notion of sustainable development, or the concept of corporate social responsibility which has grown on its basis, has resulted in a need to create a reporting system that will provide information on the methods and results of implementation of those concepts in companies. The result of inclusion of environmental and social aspects in reporting on company operations is integrated reporting, described as expanded business reporting [1]. An integrated report is a document in which the picture of the operations and the achievements of an entity (both financial and non-financial) is presented in accordance with the concept of environmental and social effectiveness, and corporate governance.

Globally, there are many organizations that not just promote but support companies in the area of integrated reporting; these include International Standards Organization, Sustainability Accounting Standards Board, Social Accountability International, and UL Environment. However, the following two organizations have gained the best reputation in this area: Global Reporting Initiative and International Integrated Reporting Committee (IIRC). The objective of the GRI is to ensure the best possible combination and continuous improvement of the guidelines for preparation of sustainability reports and an integrated reporting framework. The IIRC, on the other hand, strives 
to provide tips concerning links between financial reporting and sustainability reporting. The latter organization is also committed to encourage companies to use the guidelines created by the Global Reporting Initiative when writing their reports [2]. Both organizations and their recommended guidelines are mutually supplementary.

\section{GRI standard guidelines}

The most popular standard for reporting non-financial data is the GRI Guidelines. For many years worldwide, the Guidelines have become the standard for reporting on sustainable development and corporate social responsibility. The Guidelines are a voluntary tool that can be used by companies to prepare integrated reports that take into account the non-financial aspects of their operations, which are so important to the creation of the value of the companies. The Guidelines include principles and indicators that companies can use to measure and report their results in the economic, environmental, and social areas. The first version of the Guidelines, G1, was published in 2000 and the version that is valid now is the fourth version of the Guidelines, G4, published in 2013 [4]. The latest version makes it possible to create reports using quantifiable and comparable data. It expands the scope of social reporting in the area of involvement of stakeholders in the process of preparation of the report and emphasizes the role of the value chain.

Companies that use the GRI Guidelines in their reporting process become more attractive to their stakeholders, thus contributing to a more sustainable business practice. Moreover, the Guidelines quite flexible, which enables their use by various businesses, regardless of their size, sector, or location.

\section{Example}

Due to the unique nature of its operations and its impact on the natural environment, the energy sector should use integrated reporting. Examples of energy sector companies that present reports from their operations in an integrated manner are Iberdrola and Vattenfall.

Iberdrola is a Spanish energy sector group which has been present in the Polish renewable energy market since 2005. It focuses on designing, building, and operating wind farms [9]. Vattenfall, on the other hand, is a European energy sector corporation owned by the Swedish government. It develops and offers to its customers non-standard products based on the gas, electricity, renewable energy sources, and emission allowances markets. It also conducts trade on exchanges and OTC markets in such countries as Czech Republic, Hungary, and Slovakia [10].

Both companies actively participated in the study performed by Tim Steinweg and Joseph Wilde-Ramsing of the Centre for Research on Multinational Corporations (SOMO) as a part of the project Use of the Global Reporting Initiative in Sustainability Reporting by European Electricity Companies [5]. They reviewed sustainability reporting in 20 European energy sector companies. Their study consisted in checking:
- whether companies use the GRI Guidelines and, if they do, on what level is their application and whether their reports are internally verified;

- whether companies use the Electricity Utilities Sector Supplement (EUSS) and, if they do, they were asked to state 10 indicators;

- and in pointing at gaps in the reports of the studied companies and trying to find their causes.

Table 1. Short information on the reporting by electric utility companies (Source: author's own study on the basis of [5])

\begin{tabular}{|c|c|c|c|}
\hline & $\begin{array}{c}\text { Published } \\
\text { a CSR }\end{array}$ & $\begin{array}{c}\text { Use of } \\
\text { GRI }\end{array}$ & $\begin{array}{c}\text { Use of the } \\
\text { EUSS }\end{array}$ \\
\hline Yes & 19 & 18 & 13 \\
\hline No & 1 & 2 & 7 \\
\hline
\end{tabular}

The aforementioned companies were among the best, i.e. in the $95 \%$ of companies that publish social responsibility reports, in the $90 \%$ that use the GRI Guidelines in their reporting, and in the $60 \%$ that use the EUSS. Also, along with four other companies, their reports had applications on the highest level, which indicates broad use of GRI Guidelines and internal verification of their reports.

In the review of selected 10 indicators, Iberdrola and Vattenfall also received good scores as they reported either fully or partly on each specific indicator.

In the second part of the study, companies that were found to have any discrepancies received a draft with tips and a number of questions concerning the discrepancies that were found. The companies were allowed two weeks to answer the questions and to make corrections to the draft. Only seven companies, or $36 \%$, participated in this part of the study. Iberdrola and Vattenfall did participate, along with such companies as Dong, Fortum, RWE, Statkraft, and Verbund. Cooperation of those companies contributed to preparation of certain recommendations for various groups of stakeholders aimed to improve corporate sustainability, in particular to increase the accuracy of reporting and the credibility of the system used.

\section{Summary}

In the recent years, the great impact of the concepts of sustainable development and corporate social responsibility on company reporting, also in the energy sector, has been observed. As a result, there has been pressure on improvement of guidelines that cover presentation of information from the ESG area. The cohesive framework created by the Global Reporting Initiative and sustainable reporting are used worldwide. As the above examples show, European energy sector companies know the GRI Guidelines and use them widely. The scope of the information that is disclosed covers intangible aspects of creation of value and effectively supplements the tangible data coming from the traditional financial reporting. 


\section{Bibliography}

1. J. Krasodomska, Sprawozdawczość zintegrowanaaspekty teoretyczne i praktyczne [Integrated reporting - theoretical and practical aspects], in: M. Remlein, ed., Rachunkowość odpowiedzialności społecznej teoria i praktyka [Accounting of social responsibility theory and practice].

2. M. Mazurowska, Studia Oeconomica Posnaniensia, 3, 1 (2015)

3. Report: Challenges to sustainable development of the energy sector,

http://www.pwc.pl/pl_PL/pl/publikacje/PwC_Odpowi edzialna_energia.pdf, accessed on 23 April $2 \overline{0} 15$

4. E. Różańska, Studia Oeconomica Posnaniensia, 3 (2015).

5. T. Steinweg, J. Wilde-Ramsing, Use of the Global Reporting Initiative (GRI) in Sustainability Reporting by European Electricity Companies, Amsterdam, December 2012.

6. Report: 7 temptations of the Polish energy sector, PwC 2016.

7. Report: Directions 2014 - the energy sector DNB Bank, Deloitte 2014.

8. http://www.sii.org.pl/7595/aktualnosci/newsroom/naj wieksi-platnicy-cit-w-2014-roku.html

9. http://www.phig.pl/pl/firma/iberdrola-renewablespolska-sp-z-o-o/

10. https://corporate.vattenfall.com/aboutvattenfall/contact-us/vattenfall-poland/ 